\title{
Technical Barriers to Trade : The case of Turkey and the European Union
}

Sübidey Togan

Bilkent University, Ankara, Turkey

\begin{abstract}
The purpose of this paper is to study in detail the policies Turkey has adopted for the elimination of Technical Barriers to Trade within the context of 1995 Customs Union Decision between the EU and Turkey as of January 1, 1996. In addition, the paper emphasize the problems Turkey have encountered during the implementation of the policies, administrative costs of implementation. It is hoped that the Turkish experience will be beneficial for Southern and Eastern neighbors of the EU pursuing deeper economic integration with the EU within the context of EU's European Neighborhood Policy.
\end{abstract}

JEL Classification: F15

Keywords: Non Tariff Barriers, Technical Barriers to Trade

* Corresponding Author: Sübidey Togan; Bikent University, Deparment of Economics, 06800 Bilkent, Ankara, Turkey; Tel: +903 122901794, E-mail: togan@bilkent.edu.tr.

Acknowledgements: This paper draws materially on studies prepared for Forum Euro-Mediterranée des Instituts Economiques (FEMISE) within the context of MEDPRO project and for the World Bank. The financial support from FEMISE, supported by the European Commission, and the World Bank is greatly appreciated. I am grateful to Luc Dewulf, Jean-Pierre Chauffour, and an anonymous referee for excellent comments. 


\section{Introduction}

After pursuing inward oriented development strategies for fifty years, Turkey switched over to outward oriented policies in 1980. The policy of further opening up the economy was pursued with the aim of integrating into the European Union (EU). On March 6, 1995 it was agreed at the Association Council meeting in Brussels that a Customs Union (CU) would be created between Turkey and the EU starting January 1, 1996. According to the Customs Union Decision (CUD), all industrial goods except European Coal and Steel Community (ECSC) products circulate duty free between the parties as of January 1, 1996. In the case of ECSC products, they have received duty free treatment between the parties since 1999 as a result of a Free Trade Agreement (FTA) signed by Turkey with the EU in July 1996. Currently, no quotas and tariffs are imposed on imports of industrial goods. Turkey is implementing the Common Customs Tariff of the European Community (EC) on imports of industrial goods from third countries. On the commercial policy side, Turkey has adopted the EC competition law, established the Competition Board, adopted the EC rules on protection of intellectual and industrial property rights, and established the Patent Office.

Although more than 17 years have passed since the formation of the CU, Technical Barriers to Trade (TBTs) between Turkey and the EU could still not be eliminated; however, public authorities in Turkey are aware that the implementation of standards, quality assurance, accreditation, metrology and market surveillance are crucial for achieving competitiveness and sustained growth over time.

The welfare effects of improved access to EU markets due to harmonization of product quality standards and improvement of testing laboratories have been analyzed by Harrison et al. (1997) and Zahariadis (2005). While Harrison et al. (1997) showed that harmonization to EU standards has a very small positive effect on Turkey's welfare $(0.1 \%$ of GDP), Zahariadis (2005) indicated that the gains from abolition of TBTs amount to $0.6 \%$ of GDP.

The purpose of this paper is to study in detail the policies Turkey has adopted for the elimination of TBTs, to emphasize the problems it has encountered during this period and to estimate the administrative costs of eliminating TBTs. The paper argues that quantitative studies such as those of Harrison et al. (1997) and Zahariadis (2005) may lead to misleading results by abstracting from consideration of the administrative costs. We hope that the Turkish experience will be beneficial for Southern and Eastern 
neighbors of the EU that will pursue deeper economic integration with the EU.

The paper is structured as follows. Section II discusses standards, conformity assessment and market surveillance, while Section III concentrates on TBTs and approaches that countries can adopt for the elimination of TBTs. Section IV studies the Turkish approach for the elimination of TBTs. Section V reports estimates of the administrative costs of implementing the obligations of the $\mathrm{CU}$ for the elimination of TBTs. Section VI concludes.

\section{Standards, Conformity, and Market Surveillance}

Product standards, technical regulations and conformity assessment systems are essential ingredients of well functioning modern economies. While a standard is defined as a set of characteristics or quantities that describe features of a product, process, service or material, technical regulation is a mandatory requirement imposed by public authorities. Technical regulations and standards, despite many similarities, have different impacts. If a product does not fulfill the requirements of a technical regulation, it will not be allowed to be put on sale. In the case of standards, non-complying products will be allowed on the market; but, then, the volume of sales may be affected if consumers prefer products that meet with the standards.

Standards are developed mainly by three ways: (i) A standard may arise from a formally coordinated process in which key participants in a market, such as producers, designers, consumers, corporate and government purchasing officials and regulatory authorities seek consensus on the best technical specifications to meet customer, industry and public needs. The resulting standards are then published for voluntary use throughout industry. (ii) A standard may arise from uncoordinated processes in the competitive marketplace. When a particular set of products or process specifications gain market share, such that it acquires influence, the set of specifications is considered a de facto standard. (iii) A standard may be set by the government for which compliance is required, either by regulation or in order to sell products or services to government agencies. In this context, a procurement standard may specify requirements that must

${ }^{1}$ In the following, we use the term standards to refer to both mandatory requirements and voluntary specifications. 
be met by suppliers to the government, and a regulatory standard may set safety, environmental or related criteria.

National standards differ across countries in terms of their level of development, technology, environmental requirements, and preferences. Also, national standardization systems differ significantly with regard to their degree of centralization and participation by the government. Whereas in Western Europe, standard development activities have been largely centralized, the North American model is relatively decentralized and market oriented.

On the international level, the three predominant standards-setting bodies are the International Standardization Organization (ISO), International Electrotechnical Commission (IEC), and International Telecommunications Union (ITU). The jurisdiction of the ISO is unlimited, and in principle, the ISO may undertake standardization initiatives relating to any product or service market. It is dedicated to voluntary standardization. On the other hand, the IEC resulted from the rapid technical progress in electrical technology at the time it was established and the perception that standards were necessary to maintain a reasonable level of compatibility among electrical products. Finally, the ITU is the leading United Nations agency for information and communication technologies. As the global focal point for governments and the private sector, the ITU's role in helping the world communication spans over three core sectors: radio-communication, standardization, and development. The ITU typically develops recommendations that are implemented as national standards by national telecommunications authorities. The development process in the three organizations is lengthy and requires a majority consensus of technical committee members. Only after consensus has been reached is the standard published as an International Standard.

The assurance of confidence in claimed standards requires that a conformity assessment system comprised of testing, certification, metrology, accreditation and recognition, is well functioning. Testing is the determination of the characteristics of a product, process or service according to certain procedures, methodologies or requirements, the aim of which may be to check whether a product fulfils specifications such as safety requirements or characteristics relevant for commerce and trade. The extent of the controls that a product must undergo varies according to the risk attached to the use of the product. In low risk situations, it may be sufficient to have a declaration by the manufacturer stating that extensive testing and certification have been undertaken in accordance with certain standards. In those cases, tests are carried out by the manufacturer based on internal testing and quality assurance mechanisms, and the 
purchaser takes the manufacturer's word that the product conforms. However, in more risky situations, the manufacturer's declaration of conformity may not be sufficient. The use of independent laboratories may be required by the customer as a condition of sale or mandated by a regulatory agency. Alternatively, the purchaser may insist on formal verification by a third party that the product conforms to specific standards. In this case, certification is the procedure by which a third party gives written assurance that a product, process or service conforms to specified requirements.

The two pre-requisites for properly conducting testing and certification are metrology and accreditation. The metrology institutions, ensuring the accuracy and precision of the measurements transmitted by the calibration laboratories to other conformity assessment bodies and enterprises, build confidence in the work of conformity assessment institutions. On the other hand, accreditation refers to the procedure by which an authoritative body gives formal recognition that a body responsible for conformity assessment is competent to carry out specific tasks. Many large manufacturers require their suppliers' testing laboratories to be accredited as a condition for accepting suppliers' products. Accreditation of a laboratory's or certifier's competence in a particular field, typically involving a review of technical procedures, staff qualifications, product sample handling, test equipment calibration and maintenance, quality control, independence and financial stability. Recognition is provided by evaluation of the competence of the accreditors. $^{2}$

The final issue is related to enforcement secured through market surveillance and import controls conducted by public authorities. The main objective of these measures is to ensure that the rules summarized above are observed so that only safe products are placed on the market.

\section{Technical Barriers to Trade and their Elimination}

The benefits of standards and conformity assessment systems include facilitating market transactions, raising productive efficiency, enhancing market competition and contributing to the provision of public goods. While these functions apply across

\footnotetext{
${ }^{2}$ See National Academy of Sciences (1995), World Trade Organization (2005), and Gausch et al. (2007).
} 
borders, they can also impose additional costs to exporters and hence act as barriers to trade. TBTs are said to exist as long as countries impose different product standards as conditions for entry, sale and use of commodities; have different legal regulations on health, safety and environmental protection; and have dissimilar procedures for testing and certification to ensure conformity to existing regulations or standards.

There are essentially two ways to eliminate TBTs: harmonization and mutual recognition. The EU, starting from the 1960s until the mid 1980s, had adopted the so called Old Approach, which aimed to achieve the harmonization of product norms in as much detail as possible; however, during the 1980s, as pointed out by Messerlin (2011), it was emphasized that the Old Approach was slow, burdensome and unable to cope with the extensive variety of products that characterize modern economies. As a result, the EU adopted the New Approach, which limited the harmonization to essential requirements for protecting the common public interest in health, safety and the environment. ${ }^{3}$ The process of specification of these essential requirements in technical standards is left to European standardization bodies. Finally, under the mutual recognition principle, goods lawfully produced in one member country cannot be banned from sale on the territory of another member country, even if they are produced with different specifications; but this approach based on mutual trust by the parties requires as a minimum a relatively high degree of harmonization of standards and test procedures. According to the World Trade Organization (WTO) (2005), the Old Approach applies to products that represent about $46 \%$ of intra-EU trade, the New Approach covers products that represent nearly $17 \%$ of intra-EU merchandise trade, and the remaining $37 \%$ of trade is in products where no EU directive applies.

On the other hand, Messerlin (2011), when considering different approaches to elimination of TBTs, makes a distinction between conditional and unconditional mutual recognition. Noting that political pressures, constraints on the goods covered and discriminatory impact in the EU have tended to make the Old and New Approaches increasingly similar, he calls the EU approach to elimination of TBTs conditional mutual recognition, while the Australian approach to elimination of the TBTs is called unconditional mutual recognition. ${ }^{4}$ The 1998 Trans-Tasman Mutual Recognition Arrangement (TTMRA) between Australia and New Zealand has subjected all products to unconditional mutual recognition; but, with the incorporation of a negative list of

\footnotetext{
${ }^{3}$ See WTO (2005) for a general discussion of the harmonization approach to elimination of TBTs and European Commission (2000) for a discussion of the EU's New Approach to harmonization.

${ }^{4}$ For a discussion of the Australian approach to elimination of TBTs, see Australian Productivity Commission (2009)
} 
temporary and permanent exceptions exempting certain goods or regulations from mutual recognition, Messerlin (2011) stresses that such a negative list approach has the advantage of making exemptions very visible, which puts strong pressure on the parties for regular review. As such, according to Messerlin, the unconditional mutual recognition approach is highly desirable as long as the parties feel that they trust each other and their respective regulations so that they would be able to recognize unconditionally the partner's regulations.

\section{Turkish Approach}

The Customs Union Decision (CUD) requires that within five years, Turkey incorporates the EC instruments relating to the removal of TBTs, and the list of these instruments has to be laid down within a period of one year. Furthermore, effective cooperation is to be achieved in the fields of standardization, metrology and calibration, quality, accreditation, testing and certification. Thus, the CUD requires that Turkey adopts the harmonization approach. As a result, the elimination of TBTs in trade between Turkey and the EU requires (i) harmonization of Turkey's standards with those of the EU, (ii) harmonization of Turkey's technical legislation with that of the EU, (iii) the establishment of quality infrastructure comprised of testing, certification, metrology, accreditation and recognition as that of the EU and (iv) the development of a market surveillance and import control system as in the EU.

\section{A. Harmonization of standards}

The CUD requires that Turkey adopts the European standards developed by the European Organization for Standards, European Committee for Standardization (CEN), European Committee for Electrotechnical Standardization (CENELEC), and European Telecommunications Standards Institute (ETSI). The CUD further requires Turkey to withdraw conflicting national standards. The body in Turkey entrusted with these responsibilities is the Turkish Standards Institution (TSE), established in 1960 to draft standards for all kinds of products and services. It is entrusted with responsibility for 
the preparation and publication of the Turkish standards, industrial metrology and calibration, conformity assessment and certification and for extending awareness of quality and certification of quality systems. ${ }^{5}$ Note that CEN has an agreement with TSE through which many of the standards are developed in common.

As of 2010, TSE lists a total of 30,445 standards, of which 20,840 standards have been published in Turkish and the remaining 9,605 standards have been published only in English. ${ }^{6}$ As of 2014, Turkey has adopted a total of 22,266 CEN, CENELEC, and ETSI standards, and the overall rate of harmonization with European standards is $98.6 \%$. Besides European standards, in order to remove barriers to trade, Turkey continues to pursue the policy of adopting international standards. As of 2006, 10,167 ISO and IEC standards had been adopted as Turkish standards. Finally, it should be emphasized that Turkey is a full member of major international standards organizations such as ISO, IEC and ITU; and, as of January 2012, it is a full member of the regional standards bodies CEN and CENELEC.

\section{B. Harmonization of technical legislation}

Decision 2/97 of the Association Council listed the areas in which Turkey must align its legislation before the end of 2000, but unfortunately transposition could not be completed during the specified period because of the lack of a suitable legal infrastructure. The authorities responsible for the transposition of the relevant acquis were institutions such as the Ministry of Industry and Trade, Ministry of Public Works and Settlement, Undersecretariat for Maritime Affairs, Turkish State Monopoly on Alcohol and Tobacco and the Undersecretariat for Foreign Trade.

To align with the acquis, Law 4703 on the Preparation and Implementation of Technical Legislation on Products published in 2001 entered into force in January 2002, and it has been supplemented by secondary legislation. ${ }^{8}$ This greatly enhanced

\footnotetext{
${ }^{5}$ The founding law of the TSE of 1960 was revised in November 2011, making it compatible with EU regulations.

${ }^{6}$ It should be emphasized that in order to remove the barriers to trade, the standards published in English need to be translated into Turkish so that Turkish producers can act accordingly.

${ }^{7}$ The list of the transposed acquis through various decrees are summarized in Secretariat General for EU Affairs $(2001,2003,2007)$ and the power point presentations prepared by the Turkish side on Chapter 1 Free Movement of Goods (http://www.abgs.gov.tr/index. $\mathrm{php} ? \mathrm{p}=38 \& \mathrm{l}=2$ ).

The implementing regulations of the Framework Law consists of (i) Regulation on the Market Surveillance of Products, (ii) Regulation on the Conformity Assessment Bodies and the Notified Bodies, (iii) Regulation on the Affixing and the Use of the CE Mark and (iv) Regulation on the Notification of Technical Legislation and Standards between Turkey and the EU.
} 
harmonization works, as it provides the legal basis for harmonization with the EC legislation. It defines the principles for product safety and for implementation of the Old and New Approach directives, including the conditions for placing products on the market; the obligations of the producers and distributors, conformity assessment bodies and notified bodies; market surveillance and inspection; withdrawal of products from the market and notification procedures. ${ }^{9}$ Legislation entered into force during 2002 on the use and affixing of the Conformité Européene (CE) conformity mark, working principles and procedures for the conformity assessment bodies and notified bodies; notification procedures between Turkey and the EU for technical regulations and standards; and market surveillance. ${ }^{10}$ Turkey, during the past 19 years, has transposed and put into force 23 New Approach directives, under the coordination of the then Undersecretariat for Foreign Trade. ${ }^{11}$ On the other hand, the competent authorities have put 220 technical legislation of Old Approach into force out of approaximately 280 technical legislation of Old Approach listed by the EU-Turkey Association Council Decision No. 2/97.

In 2008, the EU with the New Legislative Framework introduced various amendments to the rules regarding accreditation, market surveillance and marketing of products. To align with the new EU regulations, Turkey revised the national legislation with the By-Law on CE Marking of February 2012, By-Law on Conformity Assessment Bodies and Notified Bodies of February 2012, Communique on Identification of Safety

\footnotetext{
${ }^{9}$ For a discussion of obligations of the producers and distributors under the related directives, see European Commission (2000).

${ }^{10}$ The notified bodies are independent testing houses, laboratories or product certifiers authorized by the EU Member States to perform the conformity assessment tasks specified in directives. A notified body is designated by a Member State and must have the necessary qualifications to meet the testing and/or certification requirements set forth in a directive. A notified body not only needs to be technically competent and capable of carrying out the specified conformity assessment procedures, but it must also demonstrate independence, impartiality and integrity. Conformance with the EN 45000/ISO 17000 standards is mandatory. Where the directives delegate conformity assessment to third parties, these are notified by national authorities to the Commission and other Member States under certain conditions. National authorities must be able to justify conformity of notified bodies through accreditation or other evidence. Certificates of conformity delivered by notified bodies must be accepted by all national authorities in the union, and suppliers may choose any notified body in the union.
}

For products regulated by the New Approach directives, the mandatory CE marking confirms conformity with the essential requirements of the directives and is required for a product to be placed on the internal market in the EU. The CE marking indicates not only that the product has been manufactured in conformity with the requirements of the directive, but also that the manufacturer has followed all the prescribed procedures for conformity assessment. It ensures free access to all of the EU, European Free Trade Association (EFTA) and Turkey.

${ }^{11}$ In 2011, the Undersecretariat for Foreign Trade (UFT), Ministry of Public Works and Settlements, Ministry of Environment and Forestry, Ministry of Transportation, Ministry of Agriculture and Rural Development and Undersecretariat for Maritime Affair were restructured. While the Ministry of Economy replaced UFT, the Ministry of Industry and Trade became Ministry of Science, Industry and Technology, Ministry of Transportation was replaced by Ministry of Transport, Maritime Affairs and Telecommunications (MTMT), Ministry of Agriculture and Rural Affairs became Ministry of Food, Agriculture and Livestock, Undersecretariat for Maritime Affairs became part of MTMT and some of the duties of the Ministry of Public Works and Settlements and of the Ministry of Environment and Forestry were transferred to the newly established Ministry of Environment and Urbanization. 
Risks for Consumer Products of April 2012 and Regulation on Market Surveillance of the Ministry of Customs and Trade of July 2012. During 2013 and 2014, Turkey adopted new regulations on automobiles and agricultural and forestry tractors; amended regulations on cosmetics; issued a new regulation on fertilizers on organic agriculture; and published regulations on transportable pressure equipment and on construction products all with the aim of aligning its legislation to the relevant EU legislation.

Although Turkey aligned its technical legislation with the acquis in the cases of commodities under the harmonized sphere, the same was not true for a very long time for commodities under the non-harmonized sphere. Since commodities under the non-harmonized sphere are governed by national laws, the EU introduced the mutual recognition principle in order to eliminate barriers to trade. ${ }^{12}$ To apply the mutual recognition principle to trade of commodities between Turkey and the EU, Turkey had to introduce legislation on mutual recognition in the non-harmonized area; but, unfortunately, the mutual recognition principle only came into force in the Turkish legal order limiting free movement of goods in the non-harmonized area on January 1, 2013.

According to the Communication 2003/C 265/02, an EU Member State of destination must allow Turkish products free access to its market provided that it offers an equivalent level of protection of the various legitimate interests involved. Thus, the EU Member State of destination has the right to verify the equivalence of the level of protection provided by the product under scrutiny, compared with that provided by its own national rules. The problem for Turkey is to avoid any kind of verification process by the EU Member States of destination by having a relatively high degree of harmonization of standards and test procedures between the parties.

\section{Quality infrastructure}

In the EU, national quality infrastructures, a generic term encompassing the operators and operation of standardization, testing, certification, inspection, accreditation and metrology, are critical to the free circulation of goods in the Single Market. Turkey, as a member of a CU with the EU and as a candidate country, must align its national quality infrastructure with that of the EU. Products manufactured in Turkey must satisfy the same requirements prevailing in the EU, and conformity to these requirements must be

\footnotetext{
${ }^{12}$ In the EU, the mutual recognition principle is governed by Directive 98/34/EC and Resolution (EC) No. 764/2008.
} 
demonstrated in the same way and according to the same principles. Furthermore, it is important to create confidence on an international level in the testing, inspection and certification bodies in Turkey and to create reliability in the tests they perform and in the certificates they issue.

After the formation of the $\mathrm{CU}$ in 1995, private conformity assessment bodies started to invest in Turkey in order to provide international certificates and markings such as the ISO 9000 series and CE marking for Turkish producers. The Turkish Accreditation Body (TURKAK) was founded in 1999 as the sole national accreditation body established by law to assess competence against internationally recognized standards of organizations that provide certification, testing, inspection and calibration services. TURKAK started accepting accreditation applications for conformity assessment bodies in 2001 . $^{13}$

In the EU, accreditation systems at the national level should be set up under the aegis of public authorities. The EU maintains that accreditation systems must be commercially independent and that accreditation services be offered in a competent, transparent, neutral, independent and non-discriminatory manner. Furthermore, the national accreditation bodies should become members of a European organization covering all countries of the EU and European Free Trade Association (EFTA) to ensure proper coordination as well as development of appropriate mutual recognition mechanisms. ${ }^{14}$ Such an organization was formed in 2000 as the European Co-operation for Accreditation (EA), which resulted from the merger of the European Accreditation of Certification and the European Co-operation for Accreditation of Laboratories.

In Turkey, different ministries are responsible for appointing notified bodies in their field of competence, and they work in cooperation with TURKAK to assess the capacity of the notified bodies and accept those that are to be notified to the EC. ${ }^{15}$ In 2002, TURKAK became a full member of the EA; however, becoming a member of an international organization is not sufficient to achieve international recognition of accreditation certificates, as an accreditation body must also be signatory to specific Multilateral Agreements (MLAs) with other accreditation bodies. In April 2006, TURKAK signed four out of seven MLAs with EA members. These four MLAs cover

\footnotetext{
${ }^{13}$ The legal framework for accreditation consists of Law 4457 on the Establishment and Tasks of the Turkish Accrediting Agency of 1999. The legal framework for conformity assessment in Turkey consists of general provisions covered by Articles 7, 8 and 9 of Framework Law 4703 relating to the preparation and implementation of technical regulation on products, published in 2001. Detailed principles can be found in the Implementing Regulation on Conformity Assessment Bodies and Notified Bodies, which was modified most recently in 2012.

${ }^{14}$ See the European Commission (1997).

${ }^{15}$ In particular, the Ministry of Industry and Trade, the Ministry of Labor and Social Security, the Ministry of Health, the Ministry of Public Works and Settlements, the Undersecretariat for Maritime Affairs and the Telecommunication Authority had established cooperation protocols with TURKAK in this context.
} 
the areas of test laboratories, calibration laboratories, quality systems management certification bodies, and inspection bodies. Hence, these certificates accredited by TURKAK have been recognized within the EU since April 2006. With the signing of the remaining three MLAs for product certification, personnel certification and environmental management systems certification in 2008, TURKAK's full international recognition has been completed. Finally, we note that the right of Turkey to assign Notified Bodies was officially recognized by the EU by virtue of the Association Council Decision No: $1 / 2006 .{ }^{16}$ Since then, the Turkish authorities have assigned a number of Turkish Notified Bodies for several New Approach directives. There are currently 23 Turkish Notified Bodies operating in areas including toys, personal protective equipment, lifts, hot-water boilers, appliances burning gaseous fuels, construction products (cement), simple pressure vessels, pressure equipment, medical devices, recreational craft and machinery.

The Turkish National Metrology Institute (UME), which is the major player regarding scientific and industrial metrology, was founded in 1992 as part of the Scientific \& Technological Research Council of Turkey and ensures the accuracy and precision of the measurements transmitted by the calibration laboratories to other conformity assessment bodies and to enterprises. Although UME is a member of the International Measurement Confederation (IMEKO), European Collaboration in Measurement Standards (EUROMET) and the European Analytical Chemistry Organization (EURACHEM), Turkey participates only in few international inter-laboratory comparisons, as emphasized by Gausch et al. (2007). Since the measurement comparisons required by the International Committee for Weights and Measures (CIPM) have become the principle reference for information on the technical capabilities of national metrology institutes, Turkey, has signed the CIPM Mutual Recognition Agreement (MRA), should participate in more comparisons to extend the scope of measurements covered by the CIPM MRA so that Turkish measurements will be recognized abroad.

The above considerations reveal that there is a relatively well functioning quality certification system in place in Turkey, comprising the Turkish Standards Institution TSE, the accreditation agency TURKAK and the National Metrology Institute UME. Because the transposition of harmonized European legislation into Turkish national

\footnotetext{
${ }^{16}$ The Association Council Decision (ACD) No 1/2006 was put into force on 15 May 2006 on the implementation of Article 9 of the $1 / 95 \mathrm{ACD}$. It regulates the rules and procedures on the allocation of identification numbers to the Turkish notified bodies.

${ }^{17}$ In July 2012, the Law on Establishment and Tasks of TÜRKAK of 1999 was amended enabling the Agency to be independent from other parties and make its decisions impartially and to be a non-profit organization. As a result TÜRKAK is compatible with EU regulations.
} 
legislation is nearing completion, there is now a need for the establishment of a soundly functioning market surveillance and import control system with improved administrative and technical infrastructure as in the EU.

\section{Market surveillance}

The legal basis for market surveillance activities consists of Law 4703 on the Preparation and Implementation of Technical Legislation on Products of 2001, the Regulation on Market Surveillance of Products of 2002 and specific product legislation and administrative legislation by public authorities in the form of circulars or communiqués. The Framework Law obliges producers to put on the market only safe products and authorizes public authorities to devise and implement productspecific legislation. Even if this legislation lacks in providing for complete safety, the related authority is still bound to monitor for complete product safety with respect to its legally established competency area. The Framework Law leaves detailed procedures and principles of market surveillance to the Regulation on Market Surveillance. In addition, each competent authority may lay down detailed procedures for its market surveillance activities in specific legislation that defines the duties and responsibilities of the inspectors and the procedures and principles for market surveillance. In 2004, a Communique was published in order to provide for a standard form to be used by all Market Surveillance Authorities (MSAs) in registering the data collected during market surveillance. In 2010, this Communique was repealed with a new one that gives MSAs the opportunity to create and use their own forms for data collection. This Communique also obliges MSAs to inform the Ministry of Economy of unsafe products identified on the market during market surveillance activities.

There are ten public authorities responsible for market surveillance and one coordinating body, the Ministry of Economy. ${ }^{18}$ An important role in the execution of market surveillance is played by the regional and provincial offices of most of the public authorities distributed throughout Turkey. The provincial offices have different executive tasks, such as inspection and sampling of products and reporting of results, dealing with

\footnotetext{
${ }^{18}$ These authorities are the Ministry of Science, Industry and Technology; Ministry of Health; Ministry of Environment and Urbanization; Ministry of Labor and Social Security; Telecommunications Authority; Ministry of Food, Agriculture and Livestock; Ministry of Transport, Maritime Affairs and Telecommunications; Tobacco, Tobacco Products and Alcoholic Beverages Market Regulatory Authority; and the Energy Market Regulatory Authority.
} 
consumer complaints and advising the public and businesses. For the coordination of market surveillance activities of the different public authorities, the Coordination Board on Market Surveillance was established in 2002 and is composed of members of the market surveillance authorities plus two members from the Ministry of Culture and Tourism and the Ministry of Transportation, Maritime Affairs, and Telecommunications. The Board, which has no executive power, is chaired by the Ministry of Economy.

In the EU, market surveillance is an essential tool to ensure a high level of health, safety, environmental and consumer protection and also a level playing field for manufactures; therefore, the national system shall ensure that only products with conformity from the relevant EC legislation may be placed on the market and shall provide for appropriate cooperation at both national and EU levels. The essential elements for an efficient market surveillance system are (i) appointing national authorities competent for monitoring conformity of the relevant products, (ii) delegating the necessary powers and resources, (iii) determining the necessary procedures such as monitoring accidents, registering and follow-up complaints, (iv) defining the necessary measures such as carrying out checks and taking samples for inspections and tests and (v) adopting rules concerning sanctions applicable to infringements.

As emphasized in reports prepared for the then Undersecretariat for Foreign Trade (2008a, 2008b), market surveillance in Turkey was facing serious problems. The reports stressed that for a large percentage of consumer products, there was no market surveillance at all; the system was fragmented and invisible; there was a substantial risk of conflict of interests; the activities were mainly directed on administrative issues, not on the safety of products, and had low priority as well; in most inspections the compliance with the General Product Safety Directive of the EU was absent; and the enforcement by inspectors was hampered by logistic problems, lack of power, and lack of experience. Thus, the reports note that the system of market surveillance in Turkey was incomplete, ineffective, and inefficient.

National Market Surveillance Reports for 2009, 2010 and thereafter that were prepared in the light of the information gathered from MSAs, include numeric data about market surveillance activities and the administrative and fiscal structure of MSAs in Turkey. It can be concluded from the data that the number of inspected products increased compared with previous years and there exist a sufficient number of accredited laboratories to be used for market surveillance activities for almost all product groups. According to the report, the number of inspectors were also increasing, but there were still some administrative and fiscal problems related with MSAs. In addition, in 2010 the 
National Market Surveillance Strategy Document was prepared and adopted in a meeting of the Market Surveillance Coordination Board. In this document, problems of the market surveillance system of Turkey were put forward with the objective of eliminating the problems. The objectives are (i) improving the legal and fiscal framework, (ii) strengthening the implementation infrastructure, (iii) developing training activities and (iv) increasing the visibility/awareness of market surveillance activities. To reach these objectives, specific goals were laid down in the Document. For many of these goals, working groups have been established chaired by several public authorities.

In 2006, a draft law on product safety was prepared to repeal Law No 4703. It laid down the rules and procedures in the non-harmonized area concerning general product safety, the obligations of economic operators (such as manufacturer, authorized representative, importer and distributer), conformity assessment and conformity assessment bodies including notified bodies, market surveillance, import controls and mutual recognition. While this work was being carried out by Turkey, the EU adopted a New Legislative Framework (NLF - Regulation No 765/2008, Regulation No 764/2008 and Decision No 768/2008) in 2008 and started the revision of the General Product Safety Directive (GPSD) No 2001/95/EC in 2010. Aiming to align to both the NLF and the revised GPSD, Turkey postponed the adoption of the above mentioned draft law. In July 2012, it adopted the above emphasized Regulation on Market Surveillance of the Ministry of Customs and Trade. The preparation of a new draft law will be launched once the revision of the GPSD is finalized by the EU.

In July 2012, Turkey adopted the Regulation on Market Surveillance of the Ministry of Customs and Trade which was amended in February 2014. In 2013 the Ministry of Science, Industry and Technology issued a regulation on market surveillance for products in its area of competence. Similarly, the Information and Communications Technologies Authority issued a regulation in the field of radio telecommunication terminal equipment.

\section{E. Import control}

Although standards are voluntary in Turkey in principle, in the absence of a proper market surveillance system, the technical ministries had turned the process of standardization and licensing before production into a mandatory regime for both domestic and imported products in order to protect the market and consumers. This pre- 
market control system gave the TSE a great deal of power.

With the Communiqué on Standardization for Foreign Trade No 2010/1, relatively few commodities classified in the 12-digit Harmonized System (HS) of tariff classification are subject to inspection by the TSE. ${ }^{19}$ All of these commodities refer to those in the unregulated area. The inspections are carried out in respect of minimum standards of health, safety and protection of the environment and thereby provide adequate information to consumers.

Because of recent developments in harmonization, the number of standards that are mandatory for the domestic market as well as for imports has substantially decreased, and it seems that the TSE's monopoly as an active player in mandatory standards controls is coming to an end. This reduction in mandatory standards brings Turkey close to having an EU-compatible control mechanism on imports from third countries; however, a remarkable difference exists in Turkey between the intensity of controls over imported products and domestic products. In principle, the same directives could apply for the surveillance of all products, whether imported or domestically produced, because import control focuses on the surveillance of goods to be imported from third countries and local products are expected to meet the same requirements as imported ones. An obvious advantage of combining import control with the surveillance of the domestic market is that the available personnel capacity can be employed on a broader scale, and cooperation with customs can be smooth and uniform.

In 2013, a decree was issued on technical regulations forming inter-ministerial basis of legislation and policy coordination carried out by the Ministry of Economy in the technical field. The decree as emphasized by the European Commission (2013) reflects a modern approach to import control based on risk analysis, and a more institutionalized approach to coordination between import control and market surveillance authorities.

\section{F. Coverage of technical regulations}

To determine those sectors and products for which technical regulations are important for Turkish exporters, we use the approach adopted by the European Commission (1998). This study provides information at the three-digit level of the Nomenclature Générale des Activités Économiques dans les Communautés Européennes (NACE) classification,

\footnotetext{
${ }^{19}$ Note that since $2002,90 \%$ of the mandatory standards applied at the import stage have been eliminated.
} 
about whether trade is affected by technical regulations and the dominant approach used by the European Commission to remove such barriers in the EU. It classifies the technical regulations under the headings of Old Approach, New Approach and mutual recognition. Following the approach of Brenton, Sheehy, and Vancauteren (2001), Togan et al. (2005) aggregate the value of Turkish manufacturing exports to the EU across the four-digit Standard Identification Trade Classification (SITC) categories, which are subject to Old Approach directives, New Approach directives, mutual recognition and a residual. The study reveals that the Old Approach applies to products that represent about $21 \%$ of Turkish exports to the EU, the New Approach covers products that represent nearly $15 \%$ of Turkish exports to the EU and $47 \%$ of Turkish exports to the EU is in products where no EU Dirative apply.

\section{G. Unconditional mutual recognition approach}

The difficulties and challenges faced by Turkey during the last 19 years raises the question of whether a system similar to the unconditional mutual recognition approach followed by Australia and New Zealand within the context of TTMRA would have been a superior method for elimination of TBTs between Turkey and the EU. The answer is probably no as Turkey until the formation of the CU neither had the quality infrastructure nor the required knowledge. Until 1996, there was no attempt on the part of Turkey to harmonize its standards with those of the EU, harmonize its technical legislation with that of the EU, establish the quality infrastructure comprised of testing, certification, metrology, accreditation, and recognition as in the EU, and develop market surveillance and import control system as in the EU. Since mutual trust by the parties require as a minimum a relatively high degree of harmonization of standards and test procedures, neither party had the desire to recognize unconditionally the other partner's regulations.

\section{Administrative Costs}

To estimate the budgetary cost of assuming the obligations of the CU for the elimination of TBTs, we use quite detailed budgetary figures of different 
public institutions. The budget figures for the Ministry of Industry and Trade and Undersecretaiat for Foreign Trade were obtained from the Ministry of Finance for the period 1994 2009, and the expenditure data for institutions such as TÜRKAK, TSE and UME were obtained from the relevant institution. ${ }^{20}$ The data were aggregated under the headings of personnel expenditures, current expenditures and investment expenditures. We use the GDP deflator (price index) to convert all figures to 2009 prices because the figures were given in nominal terms. Next, we use the average Turkish Lira/Euro exchange rate of 2009 to obtain the figures in terms of 2009 Euros.

Some of the institutions such as Undersecretariat for Foreign Trade, Ministry of Industry and Trade and TSE were operating before the start of the $\mathrm{CU}$, and they were employing a large number of personnel. The CU put pressure on these institutions not only to employ additional staff but to train the staff in issues related to relevant acquis as well. In addition, they had to increase investment expenditures. As a result, when considering the budgetary cost of assuming the obligations of the $\mathrm{CU}$ for these institutions, we concentrate on their total expenditures consisting of personnel expenditures, current expenditures and investment expenditures. ${ }^{21}$ Noting that during the period 1990 2009, Turkish real GDP increased at an annual rate of 3.9\%, we assume that total real expenditures of these institutions would have increased at the same annual growth rate as that of real GDP if the CU had not been implemented. The excess of actual to predicted expenditures by these institutions over the period 1996 2009 is then considered to be the budgetary cost of assuming the obligations of the $\mathrm{CU}$ for these institutions.

In the case of TÜRKAK, we note that it was established after 1995 as a result of the requirements of the CU. After the establishment of TÜRKAK, it had to increase its personnel expenditures and investment expenditures considerably in order to meet the demand for additional personnel, training and also to build the required infrastructure. As a result, when estimating the budgetary cost of assuming the obligations of the CU, we consider the total expenditures consisting of personnel, current, and investment expenditures over a period of five years after its establishment. Similar considerations apply to the Turkish National Metrologe Institue (UME). ${ }^{22}$

\footnotetext{
${ }^{20}$ I am grateful to Dr. Ahmet Kesik and Ali Mercan Aydin of the Ministry of Finance for providing the data and to Ertan Tok for excellent research assistance. I would like to thank Atakan Baştürk of TÜRKAK, Özcan Kuşbabalı of TSE and Adem Altuğ of UME for providing the data for TÜRKAK, TSE and UME respectively.

${ }^{21}$ In the case of the Ministry of Industry and Trade, we consider the expenditures of General Directorates that are related with the work of elimination of TBTs.

${ }^{22}$ In the case of UME, we consider the data for the period 2000 2004 because prior to 2000 the expenditures of UME were not
} 
Besides the Ministry of Industry and Trade, Undersecretariat for Foreign Trade, TSE, UME and TÜRKAK, there have been other institutions involved in the work on the elimination of TBTs such as the Ministry of Health, Ministry of Public Works and Settlement, Ministry of Environment and Forestry, Ministry of Culture and Tourism, Ministry of Agriculture and Rural Affairs, and Telecommunications Authority. In those cases, it was not possible to derive from the budget data the costs related with the elimination of TBTs; therefore, we have taken the cost figures from the studies of the Secretariat General of EU Affairs (2001, 2003, and 2007a).

Finally, we have added to the sum of the above figures, the funding received from the EU (EU contribution) because these figures were not included in the budget figures.

The estimated costs of assuming the obligations of the $\mathrm{CU}$ for the elimination of TBTs amount to 536.4 million Euros and the share of the EU contribution of the total cost of assuming the obligations of the $\mathrm{CU}$ for the elimination of TBTs is $5.6 \%$ as shown in Table 1 . The amount is considerable as it forms $0.12 \%$ of Turkish GDP. Thus, the welfare gains estimated by Harrison et al. (1997) and Zahariadis (2005) need to be adjusted by the estimated cost figures in order to arrive at net welfare gain figures for Turkey. 
Table 1. Costs of assuming the obligations of the customs union regarding the elimination of technical barriers to trade

\begin{tabular}{|l|c|c|}
\hline & $\begin{array}{c}\text { Cost } \\
\text { (in million Euros) }\end{array}$ & Percentage \\
\hline Undersecretariat of Foreign Trade & 126.15 & 23.52 \\
\hline Ministry of Industry and Trade & 22.20 & 4.14 \\
\hline Turkish Accreditation Body & 6.65 & 1.24 \\
\hline Turkish Standards Institute & 206.72 & 38.54 \\
\hline Turkish National Metrology Institute & 51.92 & 9.68 \\
\hline Ministry of Health* & 29.19 & 5.44 \\
\hline Ministry of Environment and Forestry* & 7.54 & 1.41 \\
\hline Telecommunications Authority* & 7.95 & 1.48 \\
\hline Ministry of Public Works and Settlement* & 10.07 & 1.88 \\
\hline Ministry of Agriculture and Rural Affairs* & 37.93 & 7.07 \\
\hline Ministry of Culture and Tourism* & 0.21 & 0.04 \\
\hline Funds received from the EU & $\mathbf{5 3 6 . 3 7}$ & $\mathbf{1 0 0 . 0 0}$ \\
\hline Total & & 5.57 \\
\hline
\end{tabular}

(Note) * figures are taken from Secretariat General for EU Affairs (2001, 2003, and 2007).

\section{Conclusion}

Since the formation of the Customs Union (CU) in 1996, Turkey has achieved a high level of alignment in the field of measures on standards and other technical requirements. 19 years have passed since the formation of the EU-Turkey CU. However, TBTs 
between Turkey and the EU could still not be eliminated fully. ${ }^{23}$ According to European Commission (2013), further efforts are still required in a number of areas. Technical barriers to trade still persist, both in the Old Approach area, such as on pharmaceuticals, chemicals, foodstuffs and textiles, and in the non-harmonized area as well as in market surveillance.

The reasons for the non-elimination of TBTs between Turkey and the EU are various. First, the Framework Law and associated legislation, which is the basis for the work of harmonizing the EU's technical regulations, was put into effect only in January 2002, six years after the formation of the CU. Thereafter, the adaptation process accelerated for both the new and classical approach regulations, and a large number of related regulations were adopted by Turkey. This time, however, Turkey faced another difficulty. There was no mechanism between Turkey and the EU similar to the one provided by the European Free Trade Association (EFTA) Surveillance Body, which evaluates the regulations prepared by the EFTA countries and ascertains the acceptability of these regulations by the EU. The EU-Turkey Association Council did not establish a similar body; therefore, the regulations prepared by Turkey were not evaluated by such a body and there was no mechanism to approve these regulations. Second, the number of personnel in the responsible ministries and governmental bodies who were fluent in English and trained in matters related to TBTs was insufficient. Finally, financial resources were limited for the harmonization of technical legislation.

The establishment of the quality infrastructure was a lengthy and complex process because Turkey, until the formation of the CU with the EU, had neither such an infrastructure nor the required technical knowledge. Establishing public awareness of the problem, acquiring the necessary knowledge and establishing the infrastructure took quite some time. On the other hand, the development of a market surveillance structure, as in the EU, became even more challenging than establishing the quality infrastructure. Again, the reasons are various. A successful consumer product safety related market surveillance system requires independence, visibility, a uniform surveillance policy, a uniform enforcement policy, the integration of market surveillance and import controls, stronger regions, more acting power for inspectors and sufficient technical infrastructure (Undersecretariat for Foreign Trade 2008a, 2008b). Unfortunately, the Turkish system did not meet these conditions for a long time, although considerable progress has been achieved in this respect. The continuation of these problems has adversely affected

\footnotetext{
${ }^{23}$ See European Commission (2014) and Misrahi (2010).
} 
the elimination of TBTs in trade with the EU. A major issue faced during the whole adjustment process was getting the right to assign notified bodies that would be recognized by the EU. Turkey has received this right only by virtue of the Association Council Decision No 1/2006.

The analysis in the previous section reveals that adjustment costs related to the elimination of TBTs in trade with the EU have been substantial for the Turkish public sector. In the past, Turkey has incurred these costs with the hope of becoming a full member of the EU, and they were considered as the unavoidable costs of EU accession. Other countries may not have the prospect of EU membership, but those countries may still be interested in integrating with the EU in order to achieve relatively high but sustainable economic growth measured by growth in real per capita income. In such a case, the country could try to sign an FTA with the EU; but, as emphasized by Messerlin et al. (2011), it could adopt only those policies of the EU that may be termed pro-growth.

Developing countries trying to eliminate TBTs could follow a path similar to but in some respects quite different from the Turkish one. Turkey, in order to increase access to the EU market, has followed a broad based strategy of eliminating TBTs for all industrial commodities. Instead, developing countries at the stage of development of Turkey or at a lower stage of development could concentrate their efforts on eliminating TBTs in sectors where they have a comparative advantage. Adopting the technical legislation of the major trading block would be the first step required for the elimination of TBTs. The more challenging task for southern and estern neighbours of the EU is the establishment of a quality infrastructure and market surveillance system as in the EU.

For the neighboring countries of the EU, the real issue is the recognition of their conformity assessment bodies by the EU. Turkey has been able to achieve this recognition after years of negotiations for the sectors such as machinery, construction materials and lifts where it has a comparative advantage. On the other hand, in sectors where Turkey seems to have no comparative advantage, there are still no Turkish private conformity assessment bodies recognized by the EU. In the past, the relatively large Turkish firms wishing to obtain Conformité Européene (CE) marking for products exported to the EU market contacted the local subsidiaries of the European notified bodies, which used their European laboratories for testing; however, for other Turkish companies, this process was very expensive and slow. In particular, the small- and medium-size enterprises that export products to the EU found it difficult to pay the high costs charged by the European notified bodies. Today, the neighboring countries of Turkey find it advantageous to employ the services of the Turkish conformity assessment 
bodies rather than those of the EU because the services of Turkish firms are offered at lower costs than those of EU firms. At a later time, when a developing country has reached a higher stage of development, it could extend the approach to all commodities as in the case of Turkey.

The paper concludes by summarizing the insight from the Turkish case in Appendix.

Received 11 October 2013, Revised 13 March 2014, Accepted 19 December 2014

\section{References}

Australian Productivity Commission. Review of Mutual Recognition Schemes. Productivity Commission Research Report (2009). Melbourne: Australian Productivity Commission.

Commission of the European Communities (1997), Accreditation and the Community's Policy in the Field of Conformity Assessment. CERTIF 97/4 - EN Rev.2, Brussels.

Commission of the European Communities (1998), Technical Barriers to Trade. Vol. 1, Subseries III, Dismantling of Barriers, The Single Market Review, Luxembourg: Office for Official Publications of the European Communities.

Commission of the European Communities (2000), Guide to the Implementation of Directives Based on the New Approach and the Global Approach, Luxembourg: Office of Official Publications of the European Communities.

Commission of the European Communities (2013), Turkey 2013 Progress Report, SWD(2013) 417, Brussels.

Commission of the European Communities (2014), Turkey 2014 Progress Report, SWD(2014) 307, Brussels.

Frederic Misrahi. "What Prospects for the Lifting of Technical Trade Barriers in the Mediterranean? Insights from the Turkish Case.” Mediterranean Politics 15 (2010): 189209.

Glenn Harrison, Thomas Rutherford, and David Tarr. "Economic Implications for 
Turkey of a Customs Union with the European Union." European Economic Review 41 (1997): 861-870.

J. Luis Guasch, Jean-Louis Racine, Isabel Sanchez, and Makhtar Diop. Quality Systems and Standards for a Competitive Edge. Washington D.C.: The World Bank, 2007.

National Academy of Sciences. Standards, Conformity Assessment, and Trade: Into the $21^{\text {st }}$ Century. Washington D.C.: National Academy Press, 1995.

Patrick Messerlin. "The European Union Single Markets in Goods: between Mutual Recognition and Harmonization." Australian Journal of International Affairs 65 (2011): 410-435.

Patrick Messerlin, Michael Emerson, Gia Jandieri, and Alexandre Le Vernoy. An Appraisal of the EU's Trade Policy towards its Eastern Neighbors: The Case of Georgia, Sciences Po. Paris and Centre for European Policy Studies, Brussels, 2011.

Paul Brenton, John Sheehy, and Marc Vancauteren. "Technical Barriers to Trade in the European Union: Importance for Accession Countries." Journal of Common Market Studies 39 (2001): 265-284.

Secretariat General for EU Affairs (2001), National Programme of Turkey for the Adoption of the EU Acquis, Ankara, http://www.abgs.gov.tr/index.php?p=196\&l=2.

Secretariat General for EU Affairs (2003), National Programme of Turkey for the Adoption of the EU Acquis, 2003, Ankara, http://www.abgs.gov.tr/index. $\mathrm{php}$ ? $=196 \& \mathrm{l}=2$.

Secretariat General for EU Affairs (2007), Turkey's Programme for the Alignment with the Acquis 2007 2013, Ankara, http://www.abgs.gov.tr/index.php?p=196\&l=2.

Sübidey Togan, Hüsamettin Nebioğlu, and Saadettin Doğan. "Integration and the Manufacturing Industry", in Turkey: Economic Reform and Accession to the European Union, edited by Bernard Hoekman and Sübidey Togan, 87-121. Washington D.C.: The World Bank and Centre for Economic Policy Research, 2005.

Undersecretariat for Foreign Trade (2008a), Analysis Report on Market Surveillance System in Turkey with an Emphasis on Consumer Products 'Report of the Present Situation, Report prepared within the context of Twinning Project funded by the European Commission on 'Reinforcement of Institutional Capacity for Establishing a 
Product Safety System in Turkey', Ankara.

Undersecretariat for Foreign Trade (2008b), The Way Ahead, Report prepared within the context of Twinning Project funded by the European Commission on 'Reinforcement of Institutional Capacity for Establishing a Product Safety System in Turkey, Ankara.

World Trade Organization. "Trade Standards and the WTO: The Economics of Standards and Trade" in World Trade Report 2005, 29-169. Geneva: WTO, 2005.

Yiannis Zahariadis. "A CGE Assessment of Regulatory Integration between EU and Turkey." GTAP Resource no. 1668. Purdue University: Center for Global Trade Analysis, 2005. 


\section{Appendix. Insights from the Turkish Case}

The country has to make a choice between following a broad based strategy covering all industrial commodities or a subset of industrial commodities for which the country has comparative advantage in. In either case, it would be appropriate to follow the following steps

1. Harmonization of the country's standards with those of the EU for either all industrial commodities or a subset of them requiring

- the adoption of all relevant standards developed by CEN, CENELEC and ETSI,

- adoption of all relevant international standards developed by ISO, IEC and ITU,

- the withdrawal of conflicting national standards, and

- the establishment of a standards institution compatible with EU regulations.

2. Harmonization of the country's technical legislation with that of the EU's legislation covering all industrial commodities or covering a subset of industrial commodities requiring

- the adoption of all relevant New Approach Directives,

- the adoption of all relevant Old Approach Directives,

- in the case of Mutual Recognition field (i) the establishment of trust in economic policies of the country, and in their implementation, and (ii) the achievement of a relatively high degree of harmonization and test procedures with the consent of the EU

3. Establishement of a surveillance body evaluating the regulations prepared by the country and ascertaining the acceptability of those regulations by the EU.

4. The establishment of quality infrastructure comprised of testing, certification, metrology, accreditation, and recognition as the EU's. This will require

- the establishment of National Metrology Institute

- the establishment of an Accreditation Body as in the EU, and

- getting the right to assign notified bodies for all industrial commodities or a subset 
of them that will be recognized by the EU.

5. The development of market surveillance and import control system as in the EU.

6. Training of personnel in the public sector in matters related to elimination of TBTs, and provision of sufficient financial resources to relevant institutions. 